\title{
Multidimensional Simulation of Radon Diffusion Through Earthen Covers
}

\author{
D. W. Mayer \\ G. W. Gee
}

January 1983

Prepared for the U.S. Department of Energy under Contract DE-AC06-76RLO 1830

Pacific Northwest Laboratory Operated for the U.S. Department of Energy by Battelle Memorial Institute 


\title{
DISCLAIMER
}

This report was prepared as an account of work sponsored by an agency of the United States Government. Neither the United States Government nor any agency thereof, nor any of their employees, makes any warranty, express or implied, or assumes any legal liability or responsibility for the accuracy, completeness, or usefulness of any information, apparatus, product, or process disclosed, or represents that its use would not infringe privately owned rights. Reference herein to any specific commercial product, process, or service by trade name, trademark, manufacturer, or otherwise, does not necessarily constitute or imply its endorsement, recommendation, or favoring by the United States Government or any agency thereof. The views and opinions of authors expressed herein do not necessarily state or reflect those of the United States Government or any agency thereof.

\author{
PACIFIC NORTHWEST LABORATORY \\ operated by \\ BATTELLE \\ for the \\ UNITED STATES DEPARTMENT OF ENERGY \\ under Contract DE-AC06-76RLO 1830
}

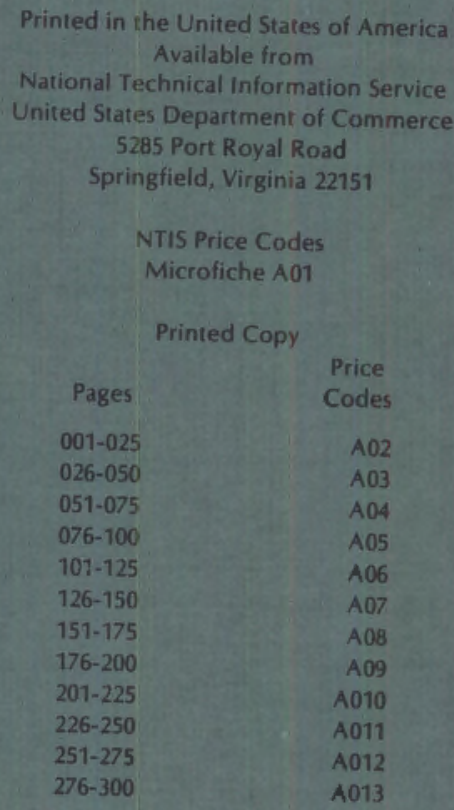


DOE / UMT-0212

PNL -4458

UC-70

MULTIDIMENSIONAL SIMULATION OF RADON DIFFUSION THROUGH EARTHEN COVERS

D. W. Mayer

G. W. Gee

January 1983

Prepared for the U.S. Department of Energy under Contract DE-ACO6-76RLo 1830

Pacific Northwest Laboratory Richland, washington 99352 



\section{SUMMARY}

Pacific Northwest Laboratory (PNL) is actively involved in the design and analysis of cover systems for uranium mill tailings. The cover systems are intended to reduce the release of radon gas from mill tailings to an environmentally acceptable level. Because it is costly to construct and monitor such systems, and it is difficult to control certain parameters in field environments, computer aided analyses have been proposed to evaluate these systems. The purpose of this report is to document applications of the RADMD model used at PNL to perform analyses of radon diffusion through uranium mill tailings cover systems.

The accuracy of the numerical formulation of the RADMD model was demonstrated through a comparison with a two-dimensional analytic solution to the radon diffusion equation. Excellent agreement was obtained between twodimensional radon concentration profiles predicted by RADMD and those obtained with the analytic solution. A simulation was made of radon diffusion into a test canister using the two dimensional capabilities of RADMD. The radon flux profile was computed and illustrates the effects of the canister on the surface radon flux. The influence of the canister on the radon flux was shown to be significant under certain circumstances.

Defects in earthen cover systems were evaluated using the three dimensional capabilities of RADMD. The results support the expectation that defective covers can increase the surface flux from a covered tailings pile. Compared to a cover with no defects, radon flux could be elevated by as much as a factor of three when $20 \%$ of the radon control layer area contained pockets of reduced moisture.

The effects of temporal and spatial variations in moisture content have been modeled by coupling RADMD with a variable saturated flow model. Twodimensional simulations were made of the time dependence of radon flux from a tailings site before and after cover placement. The results demonstrated the expected flux reduction produced by a thick earthen cover. Time dependence of the radon flux after cover placement was attributed to slight changes in mois- 
ture content of the cover material with time. The particular cover studied had a compacted clay layer that effectively attenuated the radon.

Field results from Grand Junction, Colorado were compared with onedimensional model simulations. Some field tests were in good agreement with the model predictions, but most of the tests showed large flux variations and were, in general, not predicted by the one-dimensional simulations. In the future, additional source term characterization and detailed monitoring of soil characteristics and atmospheric variables wili be required so that more reliable field data can be obtained for model verification. 


\section{CONTENTS}

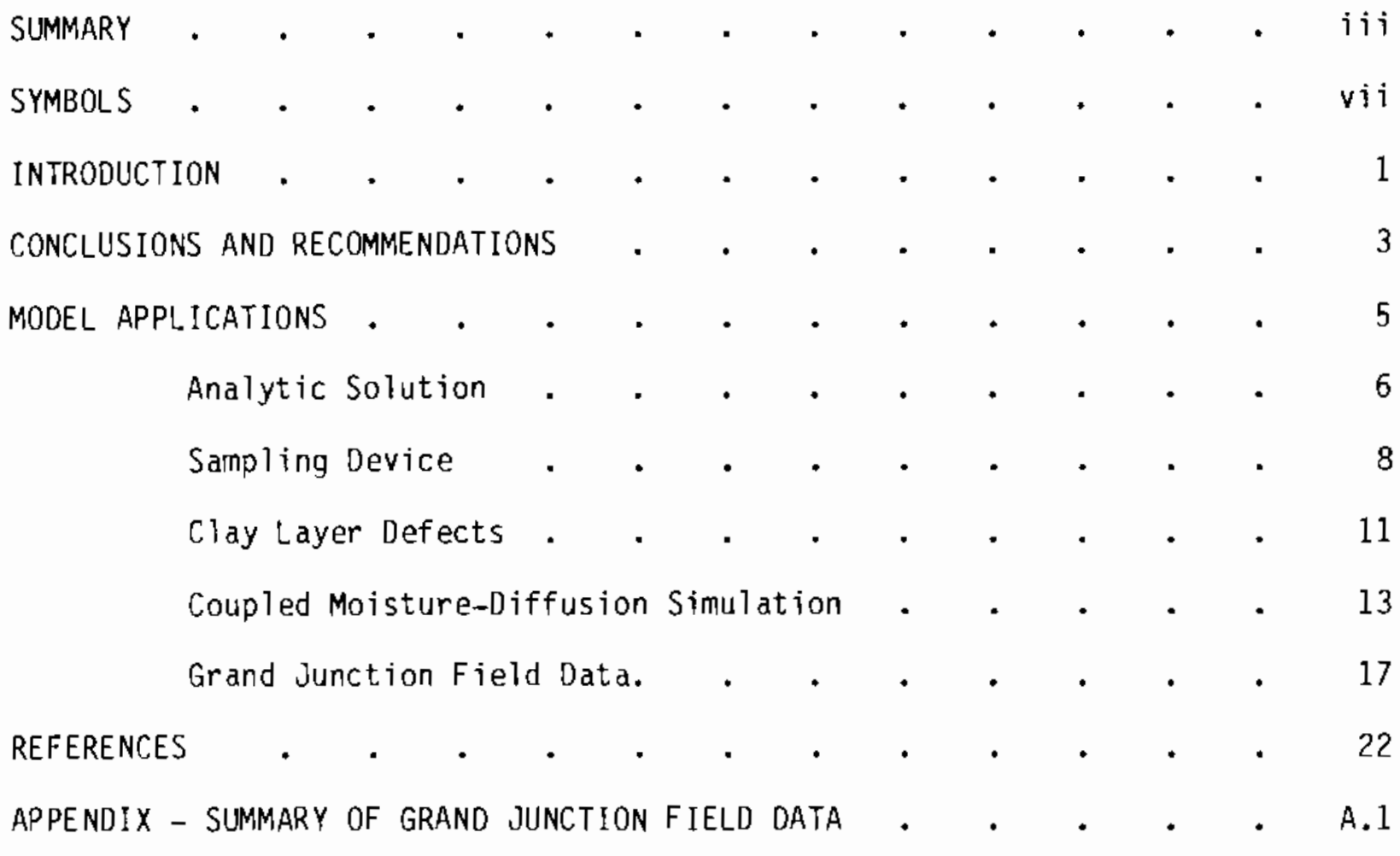




\section{FIGURES}

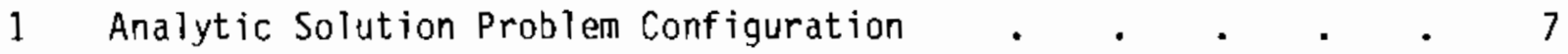

2 Surface Flux and Concentration Distribution . . . . $\quad$. 8

3 Sampling Device Problem Configuration . • • • . . . 10

4 Sampling Device Simulation Results $\quad . \quad$. $\quad . \quad$. $\quad$. $\quad$. 11

5 Multilayer Cover System for Uranium Mi11 Tailings _ . • . 12

6 Defect Locations--Plan View of Clay/Gravel Layer . . . . . 13

7 Surface Volume versus Percent Clay/Gravel Defect Volume $\quad$ - $\quad$ - 14

8a Cross Section of Pit Disposal Tailings Pile - Uncovered . . 16

8b Cross Section of Pit Disposal Taflings Pile - Covered . . . . 16

9 Average Surface Flux Before and After Pile Coverage . $\quad$ - $\quad 18$

10 Surface Flux Profiles--Uncovered Tailings Pile $\quad$ • . . . 18

11 Surface Flux Profiles-Covered Tailings Pile $\quad$ • . . . $\quad$ • 19

A.1 Schematic of Mill Tailings and Cover Layers • . . . . . A.2

\section{TABLES}

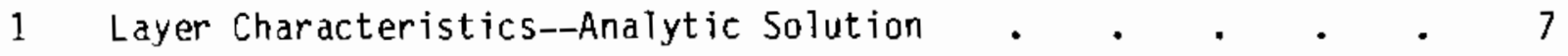

2 Layer Characteristics--Sampling Device Simulation $\quad$ - . $\quad 10$

3 Layer Characteristics--Defect Simulation $\quad$ • . . . . . 12

4 Material Characteristics--Coupled Moisture-Diffusion

Simulation . $\quad . \quad . \quad . \quad . \quad . \quad . \quad . \quad . \quad 17$

5 Comparison of Model Results and Field Observations . . . 20

A.1 Layer Thickness . . . . . . . . . . . . A.3

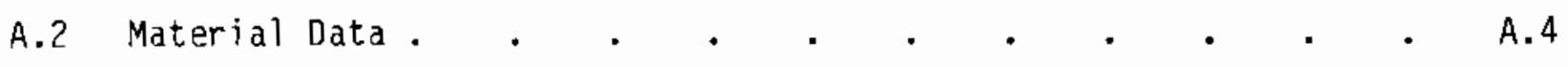




\section{SYMBOLS}

a Leading coefficient in the diffusion coefficient relationship (typical value: 0.74 )

B The exponent in the diffusion coefficient relationship (typical value: 2.16)

C Concentration of radon gas in the gas-filled pore space

D Diffusion coefficient

E Emanating power (typical value: 0.2 )

$\bar{j}$ Diffusive flux vector

$L \quad$ Thickness of a layer

P Volumetric material porosity or void fraction

R Radium content

$r \quad$ Radius

t Time

$\bar{u}$ Velocity vector

$x \quad$ Horizontal axis

z Vertical axis (typically referenced to bottom of tailings pile)

a Tortuosity

$\bar{\nabla} \quad$ Del operator $\left(\bar{\nabla}=\hat{i} \frac{\partial}{\partial x}+\hat{j} \frac{\partial}{\partial y}+\hat{k} \frac{\partial}{\partial z}\right)$

$\lambda \quad$ Decay constant

$\rho \quad$ Density

$\theta$ Volumetric moisture content (water volume/unit total soil volume) $\underline{\text { Subscripts }}$

a The property is for air

b A bulk value 
e The property is an effective value

n Layer or interface number

$S$ The value corresponds to the surface

u A value at undisturbed conditions

o A reference value

Superscripts

- A reference value 
INTRODUCTION

The diffusion of radon from uranium mill tailings through cover systems is a complex phenomenon that must be accurately taken into account when analyzing remedial action programs proposed for uranium mill tailings sites. In general, the phenomenon cannot be described by elementary calculations. Therefore, computer aided analys is of a particular proposed cover system is normally required. Pacific Northwest Laboratory, (a) under a contract with the U.S. Department of Energy's Uranium Mill Tailings Remedial Action Program (UMTRAP), has developed a multidimensional model that can be used to evaluate both edge and cover-defect effects on radon diffusion in uranium mill tailings.

This report describes the results from several computer simulations of radon diffusion through covered uranium mill tailings. In the following sections, the results of a model validation with a two-dimensional analytic solution, simulation of a defective cover system and a covered tailings pit are discussed. An attempt was also made to test the model results (one-dimensional) using field data from the Grand Junction, Colorado test site. The results presented demonstrate the model's capabilities in handing two- and threedimensional problems.

(a) Operated by Battelie Menorial Institute 


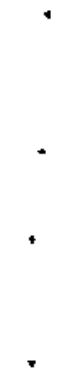




\section{CONCLUSIONS AND RECOMMENDATIONS}

The applications of the RADMD computer model, documented in this report, demonstrate the usefulness of the model for the analysis of covered uranium mill tailings systems. It is demonstrated that the model can solve one-, two- and three-dimensional steady state problems as well as two-dimensional transient problems. In addition, the model has been coupled with a variably saturated flow model, which results in a more complete description of the complex radon diffusion phenomenon that occurs in covered uranium mill tailings. The accuracy of the model is proven by validation with an available analytical solution. Wide variations in field measured values of radon flux made model simulation of field results difficult. The large observed variations in radon flux were not accounted for by measured moisture changes with depth or time. Additional factors besides moisture and density appear to be important in assessing the radon flux variability. Better characterization of radon source terms and more detailed monitoring of soil variables, including moisture and density changes, will be required before accurate simulations of field measurements of radon flux can be realized. 


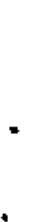
. 
MODEL. APPLICATIONS

The analyses presented in the following subsections have been performed with the aid of the RADMD computer code (Mayer et a1. 1981). This code solves the general radon diffusion equation, which can be expressed as follows (Nelson et al. 1980):

$$
\begin{aligned}
\frac{D}{D t}[(P-\theta) C] & \equiv \frac{\partial[(P-\theta) C]}{\partial t}+\bar{u} \cdot \bar{\nabla}[(P-\theta) L] \\
& =\bar{\nabla} \cdot D_{e} \overline{\nabla C}-(P-\theta) \lambda C+R \rho_{b} \lambda E
\end{aligned}
$$

where

$(P-\theta)=$ gas-filled pore space in the porous material

$P=$ material porosity or void fraction on a volume basis

$\theta=$ moisture content on a volume basis (water volume/unit total soil volume)

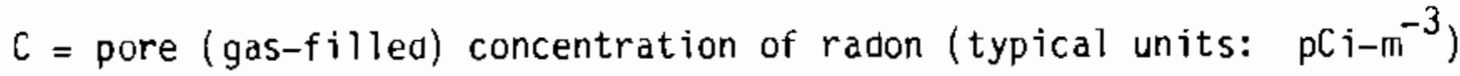

$\bar{u}=$ velocity vector (typical units: $\mathrm{m}^{-\mathrm{s}^{-1}}$ )

$D_{e}=$ effective diffusion coefficient (typical units: $m^{2}-s^{-1}$ )

$\lambda=$ decay constant for radon (typical units: $s^{-1}$ )

$R=$ radium $\left({ }^{226} \mathrm{Ra}\right)$ content in the porous material (typical units: $p\left(i-g^{-1}\right)$

$E$ = emanating power of the material, which is slightly dependent upon the moisture content, particularly at very low moisture content (see Tanner 1964).

Note that this formulation is based on the concentration in the gas-filled pore space, not on the concentration in the total pore space. The bulk diffusive flux vector, $J$, is calculated from Fick's law as follows:

$$
\bar{J}=-D \bar{\nabla} C
$$


The numerical formulation of RADMD is based on integrated finitedifference techniques. The program can be used to analyze a broad class of problems ranging from one-dimensional and steady-state to three-dimensional and transient simulations. In addition, Cartesian, cylindrical, and spherical coordinate systems $c$ an be used, irregular geometries are readily accounted for, and heterogeneous systems can be modeled. In light of the trend toward computer modeling in the design of cover systems for uranium mill tailings, the benefits of a model that can be applied to all conceivable configurations is apparent. It is an advantage of the RADMO formulation that approximate solutions to the radon equation are not required. In addition, the assumption of one-dimensional radon movement or steady-state conditions is not required but can be readily made if these assumptions are warranted.

This report demonstrates some of the capabilities of the RADMD code. The model predictions have been compared with a two-dimensional analytic solution to the raoon diffusion equation and several simulations of probiems pertinent to uranium mill tailings management have been performed. These applications of the model are discussed in the following subsections.

Analytic Solution

In an earlier report (Mayer et al. 1981), RADMD was verified with a onedimensional solution to the radon diffusion equation. Since many of the model applications involve multidimensional simulations, it was advisable to check the model's ability to match a two-dimensional analytic solution. Several solutions have been reported (Sandquist et al. 1981) for axisymmetric geometries. Orie of these solutions was chosen for comparison with the results predicted by RAOMD.

A sketch of the problem geometry is shown in Figure 1 . Table 1 lists the parameters used for each layer. The surface boundary condition was specified by the following relationstip:

$$
\begin{aligned}
& c(r)=c_{u}\left\{1+0.4\left[1-2\left(\frac{r}{r_{0}}\right)^{2}+\left(\frac{r}{r_{0}}\right)^{4}\right]\right\} \\
& \quad \text { for } 0<r<r_{0}
\end{aligned}
$$




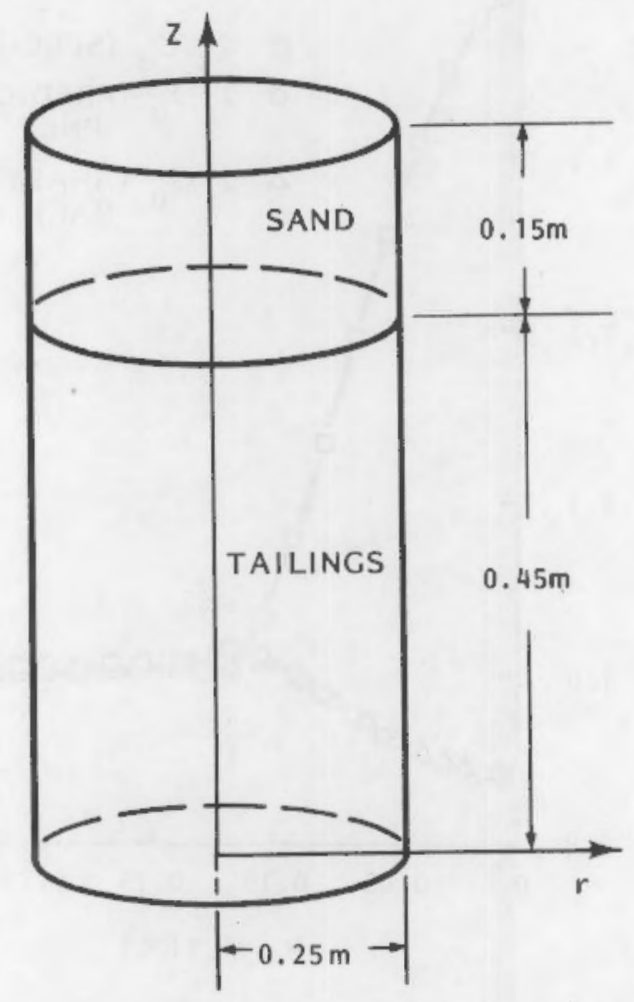

FIGURE 1. Analytic Solution Problem Configuration

TABLE 1. Layer Characteristics--Analytic Solution

\begin{tabular}{|c|c|c|c|c|c|c|c|}
\hline Layer & $\begin{array}{c}\text { Thickness, } \\
\text { m }\end{array}$ & $P$ & $m^{3}-m^{-3}$ & $\begin{array}{c}\mathrm{De}_{\mathrm{e}} \\
\mathrm{m}^{2}-\mathrm{s}^{-1} \\
\end{array}$ & $\begin{array}{c}R \\
p C i-g^{-1} \\
\end{array}$ & $E$ & $\begin{array}{l}{ }_{\mathrm{b}} \\
\mathrm{g}-\mathrm{m}^{-3}\end{array}$ \\
\hline Sand & 0.15 & 0.35 & 0.00 & $1.23 \cdot 10^{-6}$ & 0.0 & 0.0 & $1.755 \cdot 10^{6}$ \\
\hline Tailings & 0.45 & 0.48 & 0.05 & $1.21 \cdot 10^{-6}$ & 1092.0 & 0.2 & $1.400 \cdot 10^{6}$ \\
\hline
\end{tabular}

where

$$
\begin{aligned}
r_{0} & =0.125 \mathrm{~m} \\
r_{\max } & =0.25 \mathrm{~m} \\
C_{u} & =1.7 \cdot 10^{6} \mathrm{pCi}-\mathrm{m}^{-3} .
\end{aligned}
$$

At the bottom of the tailings layer, a zero flux boundary condition was imposed.

The resulting steady-state surface flux values predicted by RADMD are plotted in Figure 2. The normalizing values are the undisturbed surface flux 


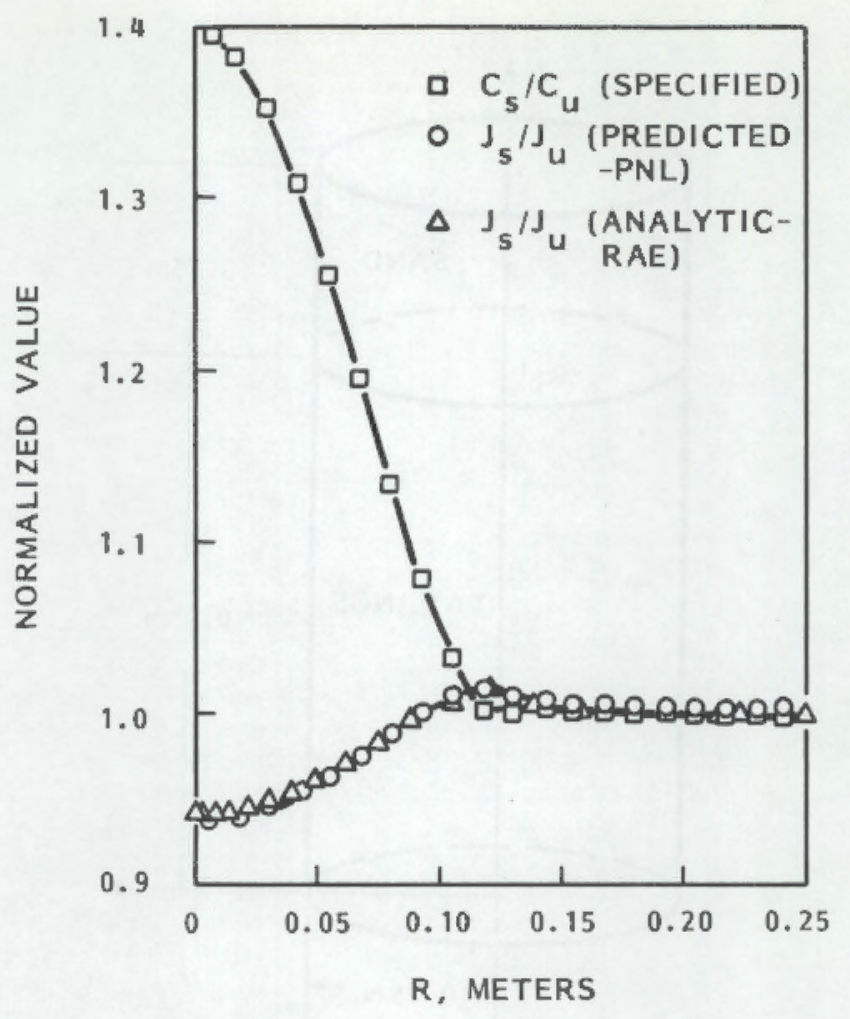

FIGURE 2. Surface Flux and Concentration Distribution

$\left(J_{u}=260.0 \mathrm{pCi}-\mathrm{m}^{-2}-\mathrm{s}^{-1}\right)$ and the undisturbed surface concentration

$\left(C_{u}=1.7 \cdot 10^{6} \mathrm{pC} i-\mathrm{m}^{-3}\right)$, which results in a surface flux of $J_{u}$.

The analytic results were obtained by Sandquist et al. (1981). Since the analytic solution is applicable to only a single homogeneous layer, the solution was calculated for the sand layer only. The surface boundary condition was specified by Equations 2 and 3 . The boundary condition at the bottom of the sand layer was a specified flux of $261.7 \mathrm{pCi}_{-} \mathrm{m}^{-2}-\mathrm{s}^{-1}$. This value was based on the flux at the sand/tailings interface predicted by RADMD. It is apparent from Figure 2 that the results predicted by RADMD are in excellent agreement with the analytic solution. The two solutions differ by $<1 \%$, verifying the model's ability to solve radon diffusion problems in two dimensions.

\section{Sampling Device}

It is often necessary to measure radon gas emissions from uranium mill tailings. The task can be accomplished by placing a canister on the surface of the tailings pile. Various configurations of a canister device for radon flux have been tested (Nielson et al. 1981). For short term measurements 
(minutes), the canister is often empty and is used simply to accumulate radon gas which is sampled with time. More typically, the canister contains some activated charcoal which adsorbs radon over a relatively long time period (hrs to days). By measuring the amount of radon collected in the canister, a determination of the radon flux can be made. In either case the placement of the sampling device affects the surface flux. The following simulation was performed to investigate this effect.

The problem configuration is shown in Figure 3 . The layer characteristics are listed in Table 2. The boundary conditions for this simulation are zero flux along the top and sides of the sampling device, at the bottom of the tailings, and along the sides of the tailing and sand layers. A zero concentration was imposed at the exposed surface of the sand layer. Radon gas concentration builds up with time in the canister. The simulation was run until steady state conditions were achieved. The resulting radon flux along the sand surface is plotted in Figure 4 . The flux values in Figure 4 have been normalized by $J_{u}$, the surface flux that results when no sampling device is present $\left(J_{u}=\right.$ $\left.260.0 \mathrm{pC} i-\mathrm{m}^{-2}-\mathrm{s}^{-1}\right)$. Notice that for this specific configuration, the radon flux under the sampling device has been reduced to one-half the undisturbed value and, near the edge of the device, the radon is actually diffusing back into the sand layer.

For a large canister with a small amount of charcoal the canister placement on the tailings can significantly alter the radon flux measurement particularly if a long time period (1 day or more) is used. Although the sink term produced by the charcoal was not modeled in the test case, it would need to be included for accurate evaluation of the canister effect on the flux. However, the simulation illustrates the extreme example of the flux attained under conditions where the flux is very large compared to the rate of sorption on the charcoal.

The partition coefficient or sorption efficiency (amount of radon sorbed to that remaining in air) and the amount of charcoal present would need to be specified in order to properly model the sink term. For shorter time periods (a few hours) and large amounts of charcoal the effect of the canister on the flux could be minimized. Since the model is capable of simulating multidimensional configurations and analyzing transient (time dependent) cases it 


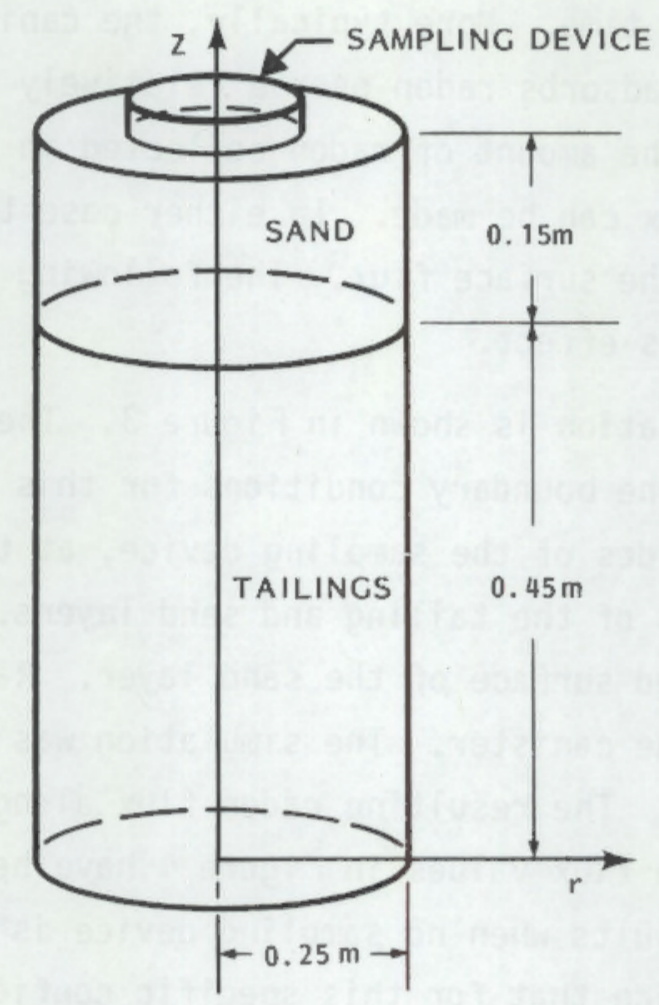

FIGURE 3. Sampling Device Problem Configuration

TABLE 2. Layer Characteristics--Sampling Device Simulation

\begin{tabular}{|c|c|c|c|c|c|c|c|}
\hline Layer & $\begin{array}{c}\text { Thickness, } \\
\mathrm{m}\end{array}$ & $m^{3}-m^{-3}$ & $m^{3}-m^{-3}$ & $m^{2}-s^{-1}$ & $\begin{array}{c}R \\
p C i-g^{-1}\end{array}$ & $E$ & $\begin{array}{c}\rho_{b} \\
g-m^{-3}\end{array}$ \\
\hline $\begin{array}{l}\text { Sampling } \\
\text { Device } \\
\text { (A ir) }\end{array}$ & 0.04 & 1.00 & 0.00 & $1.00 \cdot 10^{-5}$ & 0.0 & 0.0 & -- \\
\hline Sand & 0.15 & 0.35 & 0.00 & $1.23 \cdot 10^{-6}$ & 0.0 & 0.0 & $1.76 \cdot 10^{6}$ \\
\hline railings & 0.45 & 0.48 & 0.05 & $1.21 \cdot 10^{-6}$ & 1088.8 & 0.2 & $1.40 \cdot 10^{6}$ \\
\hline
\end{tabular}

is a useful analytical tool in evaluating the design of a radon flux measuring device. Test cases using various configurations could be run to optimize the size of the canister and the amount of charcoal needed for a given tailings radon source. 


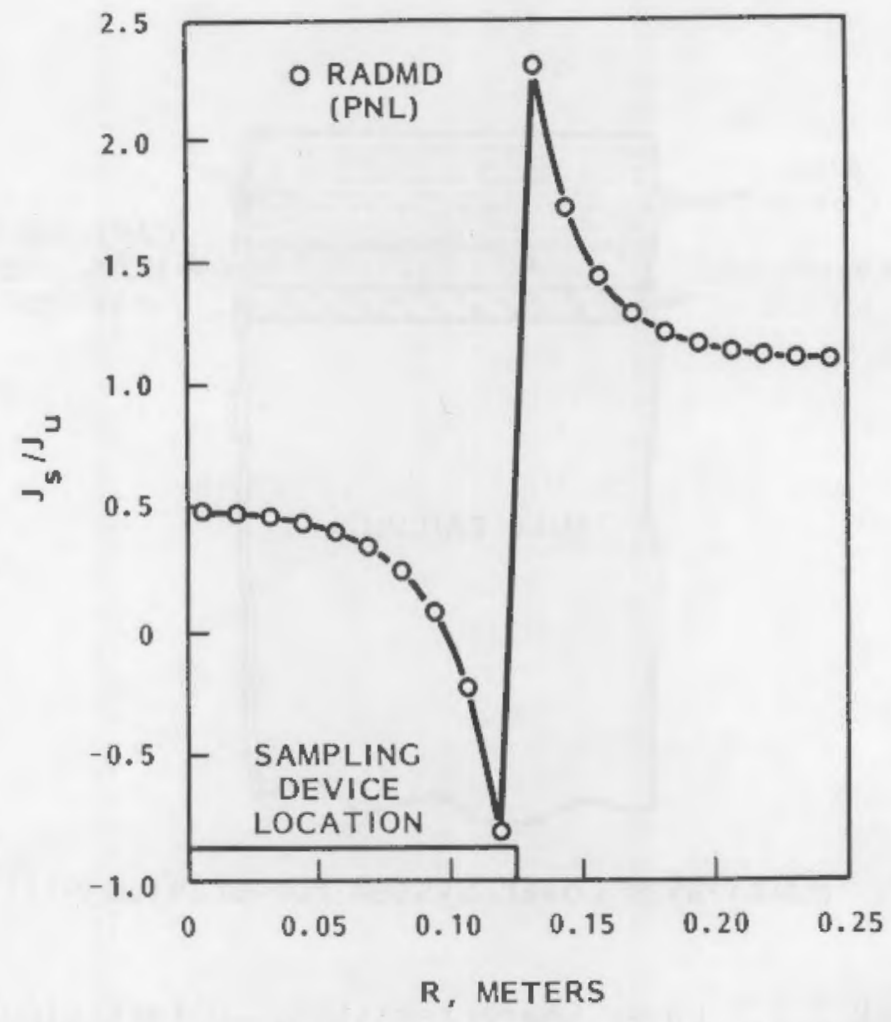

FIGURE 4. Sampling Device Simulation Results

\section{Clay Layer Defects}

During the construction of test cover systems at Grand Junction, Colorado, difficulty was experienced in producing homogeneous cover layers (Gee et al. 1981). In particular, the clay/gravel mix (Figure 5) was found to have pockets consisting mainly of gravel. Later measurements showed marked variation in the surface radon flux. Some of these variations were attributed to the grave 1 pockets. Model simulations were conducted to investigate the effect on the surface flux of randomly located defects in the clay/gravel layer.

The analysis consisted of a three-dimensional simulation of the multilayer cover system shown in Figure 5 . The region simulated was a column $1.80 \mathrm{~m}$ square and $7.60 \mathrm{~m}$ deep that consisted of the materials listed in Table 3 . The defects were regions $0.2 \mathrm{~m}$ square and $0.3 \mathrm{~m}$ deep that penetrated the clayl gravel layer. The defects were randomly located in the clay/gravel layer with the aid of a random number table (see Figure 6 for defect locations). 


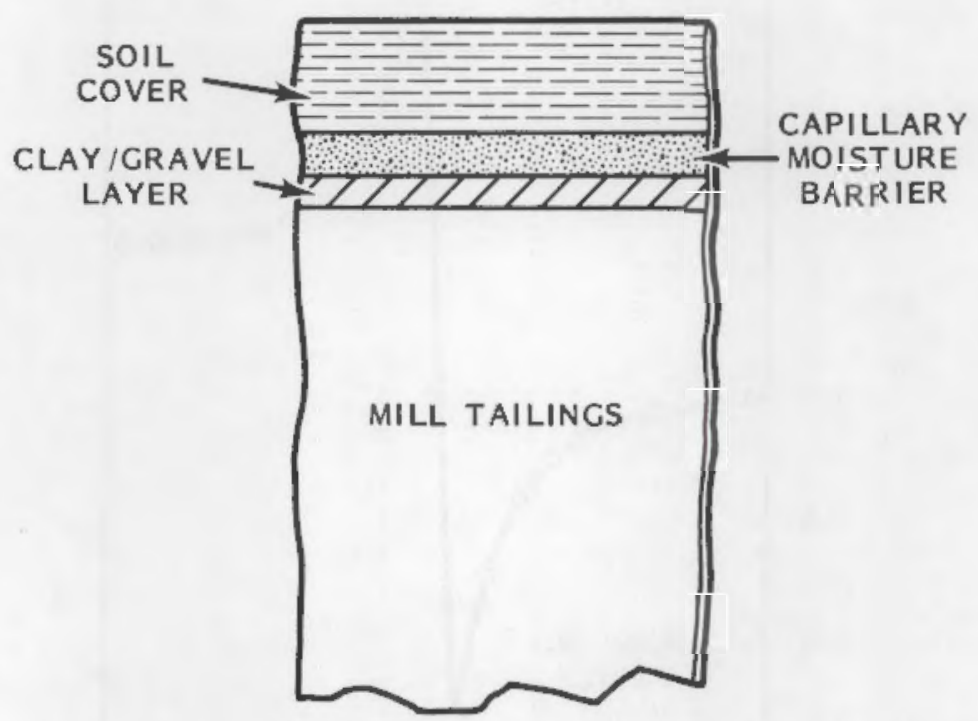

FIGURE 5. Multilayer Cover System for Uranium Mill Tailings

\section{TABLE 3. Layer Characteristics--0efect Simulation}

\begin{tabular}{|c|c|c|c|c|c|c|c|c|}
\hline Layer & & $\begin{array}{c}\text { Thickness, } \\
\mathrm{m}\end{array}$ & $\begin{array}{c}{ }^{\rho_{b}} \\
g-m^{-3}\end{array}$ & $\begin{array}{c}m^{P} \\
m^{3}-m^{-3} \\
\end{array}$ & $m^{3}-m^{-3}$ & $m^{2}-s^{-1}$ & $\begin{array}{c}R \\
\mathrm{pC} i-\mathrm{g}^{-1} \\
\end{array}$ & $E$ \\
\hline 4 & Soil & 1.0 & $1.46 \cdot 10^{6}$ & 0.46 & 0.11 & $7.62 \cdot 10^{-7}$ & 0 & 0.0 \\
\hline 3 & Rock & 0.3 & $1.70 \cdot 10^{6}$ & 0.37 & 0.02 & $7.66 \cdot 10^{-7}$ & 0 & 0.0 \\
\hline 2 & $\mathrm{Cl}$ ay/gravel & 0.3 & $2.00 \cdot 10^{6}$ & 0.26 & 0.20 & $0.64 \cdot 10^{-8}$ & 0 & 0.0 \\
\hline 2 & $\begin{array}{c}\mathrm{Clay} / \text { gravel } \\
\text { defect }\end{array}$ & 0.3 & $1.70 \cdot 10^{6}$ & 0.37 & 0.10 & $4.38 \cdot 10^{-7}$ & 0 & 0.0 \\
\hline 1 & Tailings & 6.0 & $1.23 \cdot 10^{6}$ & 0.54 & 0.19 & $7.86 \cdot 10^{-7}$ & 1600 & 0.2 \\
\hline
\end{tabular}

Five model simulations were performed for cases involving 2, 8, and 16 defective regions, a case with no defective regions, and a case where the clay/gravel layer was wholly defective. The results are plotted in Figure 7 as the normalized average surface flux, versus the percentage of the clayl gravel layer volume that is defective. As expected, the presence of defects in the clay/gravel layer can have a significant impact on the surface emission 


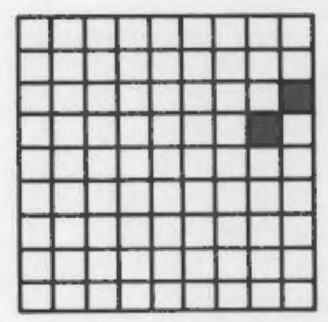

2 DEFECT SIMULATION

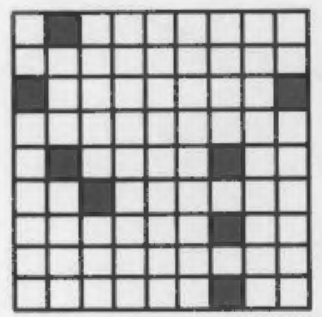

8 DEFECT SIMULATION

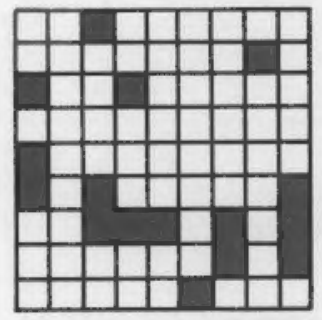

DEFECT REGIONS

16 DEFECT SIMULATION

FIGURE 6. Defect Locations - Plan View of Clay/Gravel Layer

of radon gas. For a case where $20 \%$ of the clay/gravel layer was defective, the surface flux was increased over 3 times the flux that would be observed with no defects in the clay/gravel layer.

Coupled Moisture-Diffusion Simulation

It is well known that the moisture content, $\theta$, of a porous material strongly affects the diffusion of radon through the material. Since the moisture content $c$ an be affected by many factors, including drainage, evaporation, infiltration, and plant transpiration, it is necessary to account for these factors in a transient analys is of uranium mill tailings and cover systems. RADMD can account for moisture variations by changing the air-filled porosity, $P-\theta$, and the effective diffusion coefficient, $D_{e}$, to reflect the transient moisture content. To do this it is necessary to run a saturated-unsaturated 


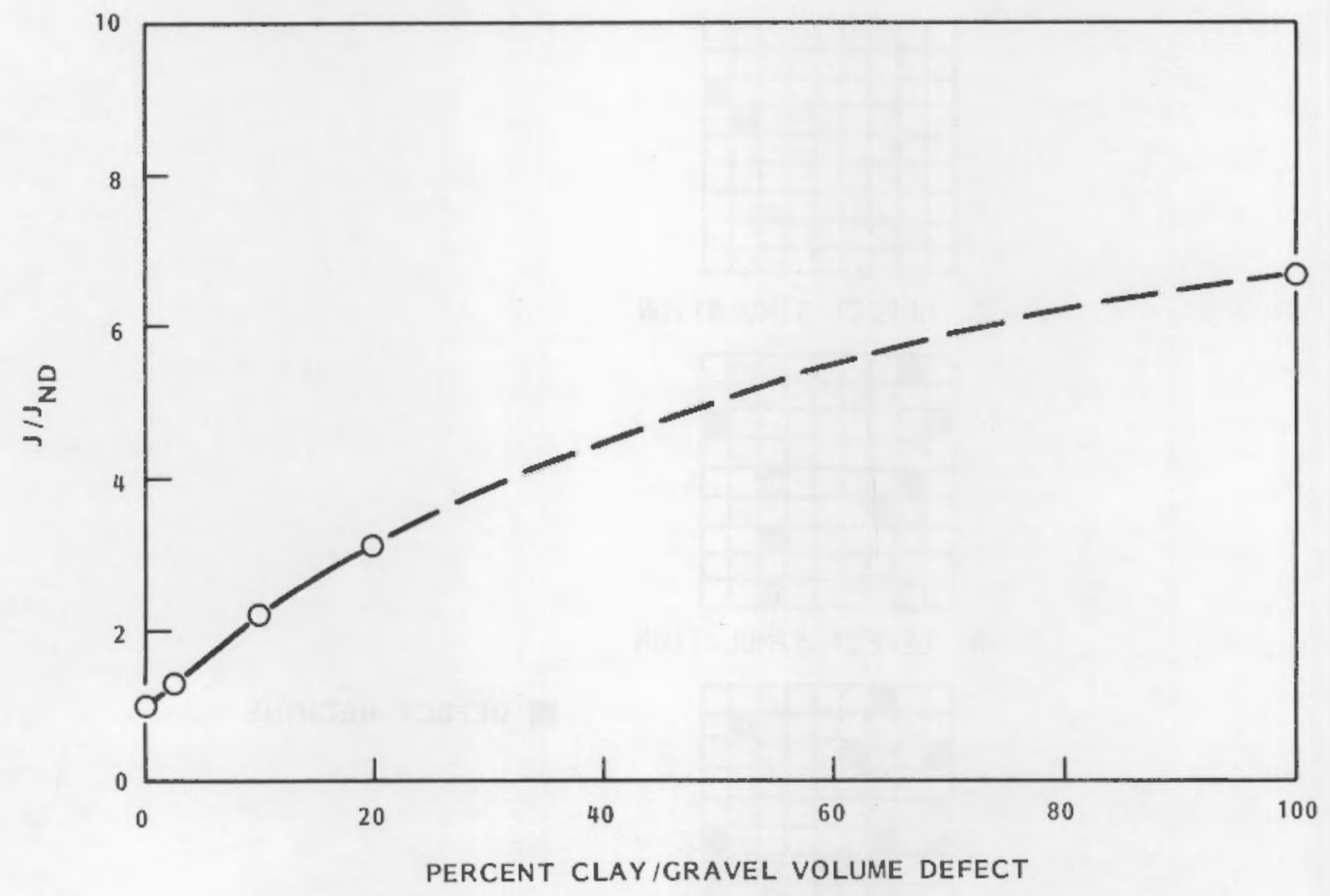

FIGURE 7. Surface Volume versus Percent $\mathrm{Clay} / \mathrm{Gravel}$ Defect Volume

flow analys is of the system to obtain the spatial and temporal variations in $\theta$. Then the effective diffusion coefficient is calculated from the local moisture content and air-filled porosity via an empirical correlation. The correlation used for this study is as follows (Nelson et al. 1980):

$$
D_{e}=a D_{a}^{0}(P-\theta)^{B}+D_{w}^{0} \alpha \theta
$$

where

$a=$ an empirically determined coefficient (typical value: 0.740 )

$D_{\mathrm{a}}^{\circ}=$ the radon diffusion coefficient in air (typical value:

$$
1.0 \cdot 10^{-5} \mathrm{~m}^{2}-\mathrm{s}^{-1} \text { ) }
$$

$B=$ an empirically determined coefficient (typical value: 2.16)

$D_{W}^{\circ}=$ the radon diffusion coefficient in water (typical value:

$$
1.0 \cdot 10^{-9} \mathrm{~m}^{2}-\mathrm{s}^{-1} \text { ) }
$$

$a=$ the tortuosity (typical value: 0.66 ). 
It should be noted that other correlations have been used to relate moisture content to radon diffusivity in soil covers (Rogers et al. 1980). We found it convenient to use Equation 5 since it readily accounts for density variations in multilayer cover systems. The air-filled porosity formulation (Equation 5) accounts for moisture and density effects on the diffusion coefficient while the Rogers correlation (Rogers et al. 1980) is based only on moisture content and does not properly account for variations in cover density.

The problem chosen to demonstrate the ability of RADMD to account for transient moisture content is a pit disposal system whose cross section is shown in Figure 8 . The region modeled consists of an area that is $275.0 \mathrm{~m}$ wide by $51.5 \mathrm{~m}$ deep (see Figure $8 \mathrm{~b}$ ). The cover (consisting of overburden and a sloping clay cap) is $7 \mathrm{~m}$ deep. The tailings are $26 \mathrm{~m}$ deep and lie over a $0.9 \mathrm{~m}$ thick clay liner and $9.1 \mathrm{~m}$ of backfilled overburden. The purpose of the backfill is to raise the tailings above the water table. The width of the tailings is $200.0 \mathrm{~m}$ at the surface with side walls that slope at $26.5^{\circ}$ from the vertical. The material properties used in the simulations are summarized in Table 4.

The first step in analyzing this problem was to construct a grid of approximately 550 nodes to represent the region shown in Figures $8 \mathrm{a}$ and $8 \mathrm{~b}$. Next, the variably saturated flow code TRUST (Narasimhan and Witherspoon 1977, Reisenauer et al. 1982) was used to generate temporal and spatial variations of the moisture content. The simulation was performed in two stages. First the pit was assumed to be filled with initially saturated tailings. The tailings were allowed to drain for 450 days. Then the cover consisting of the overburden material and the sloping clay cap was added at nearly saturated conditions. The simulation was continued from this point in time for another 3 months.

Based on the resulting moisture content values, diffusion coefficients for each node were computed using Equation 5. A plot of the average surface flux versus time for the 2 months preceeding and 3 months following cover application are shown in Figure 9. Note the effectiveness of the cover in attenuating the radon emissions. The degree of attenuation is greater than would actually occur since the cover materials were applied at a nearly saturated state.

In Figure 10 the flux profiles before cover application are shown. The flux from the tailings zone is a nearly constant value of $275 \mathrm{pCi}-\mathrm{m}^{-2}-\mathrm{s}^{-1}$ 


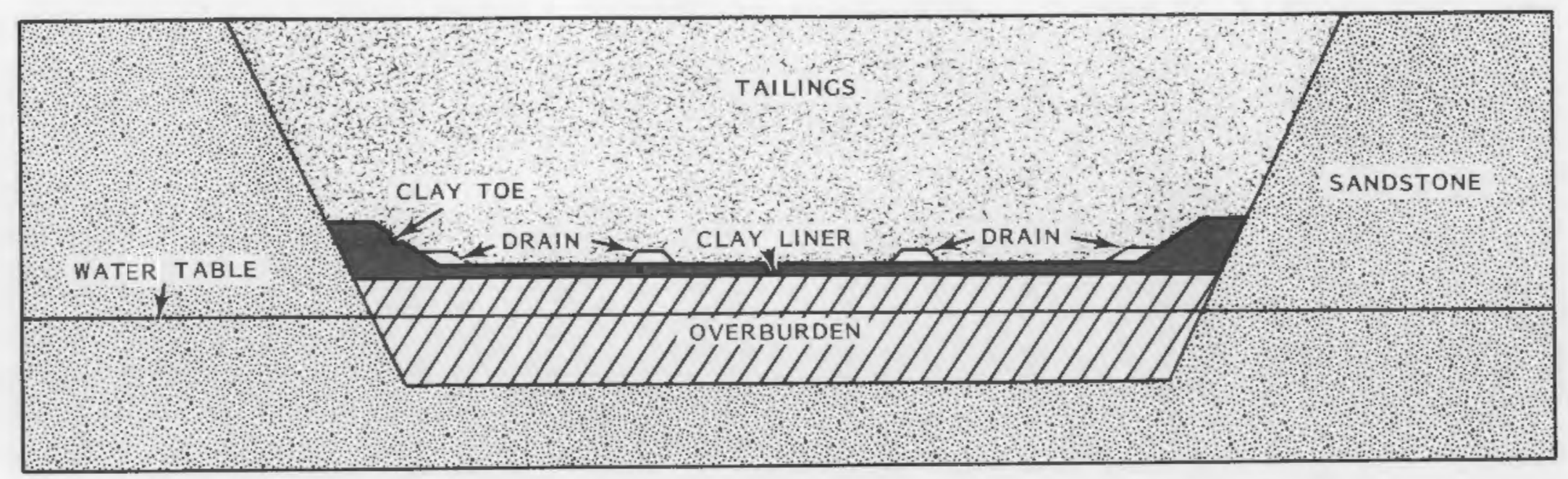

FIGURE 8a. Cross Section of Pit Disposal Tailings Pile - Uncovered

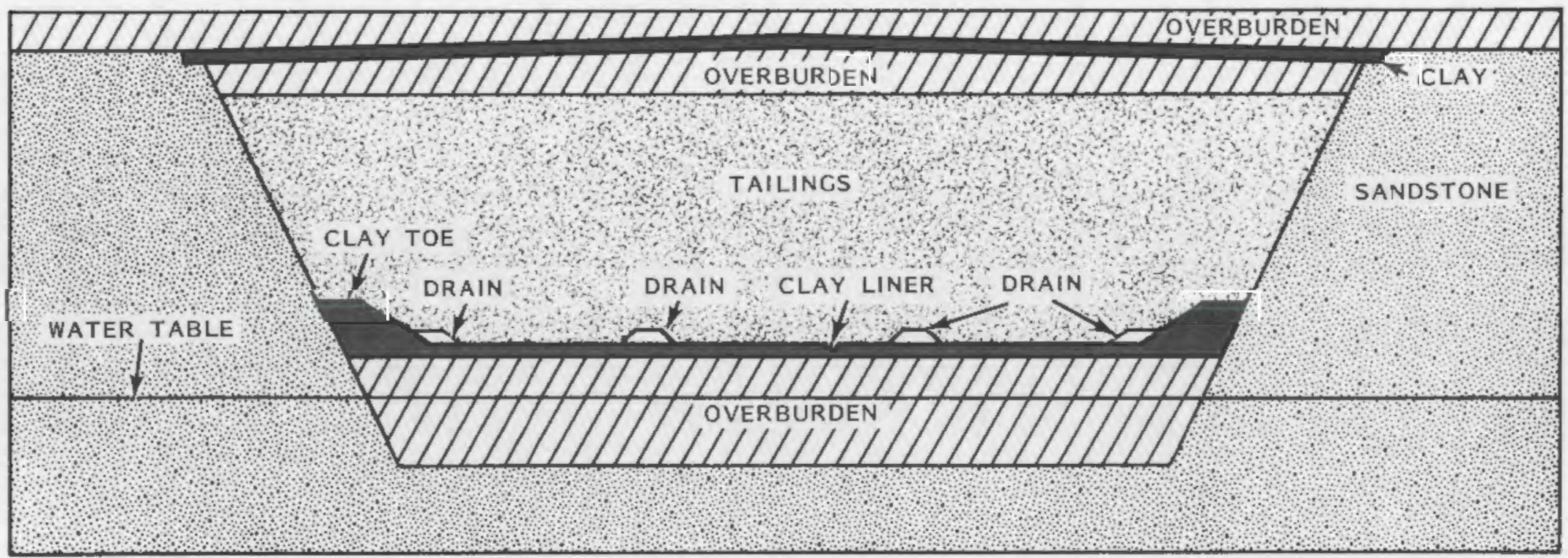

FIGURE 8b. Cross Section of Pit Disposal Tailings Pile - Covered 
TABLE 4. Material Characteristics--Coupled Moisture-Diffusion Simulation

\begin{tabular}{|c|c|c|c|c|}
\hline Material & $\begin{array}{c}P_{b} \\
g-m^{-3}\end{array}$ & $\begin{array}{c}P \\
m^{3}-m^{-3} \\
\end{array}$ & $\begin{array}{c}R \\
p C i-g^{-1} \\
\end{array}$ & $E$ \\
\hline Overburden & $1.65 \cdot 10^{6}$ & 0.389 & 0 & 0.0 \\
\hline Clay & $1.69 \cdot 10^{6}$ & 0.385 & 0 & 0.0 \\
\hline Drains & $1.70 \cdot 10^{6}$ & 0.358 & 0 & 0.0 \\
\hline Sandstone & $1.75 \cdot 10^{6}$ & 0.340 & 0 & 0.0 \\
\hline Tailings & $1.63 \cdot 10^{6}$ & 0.440 & 1600 & 0.2 \\
\hline
\end{tabular}

except near the edge of the tailings. The sharp increases near the edge of the tailings zone is due to the coarse-mesh grid used in this region. In fact, the use of too coarse a mesh generally results in an underprediction of the surface flux by 15 to $20 \%$. This inaccuracy arises because the concentration profile is not represented accurately enough at the surface, and the surface flux calculation will therefore be in error.

Figure 11 is a plot of the surface flux profiles for the last 3 months of the simulation (cover in place). As expected, the application of the cover initially reduces the radon emissions to zero. As the radon diffuses through the cover, the surface flux increases. Note that the flux increase is slowing by the end of the simulation and the flux magnitude has been reduced by approximately four orders of magnitude (relative to the uncovered values). Grand Junction Field Data

It has not yet been demonstrated that the RADMD model accurately simulates field conditions. This section deals with the simulation of 14 test cases that are based on field data from PNL's test sites at Grand Junction, Colorado. A detailed description of the cover systems tested is given by Hartley and Gee (1981).

The simulations have been performed assuming one-dimensional vertical radon diffusion. The characteristics of the material layers for each of the 14 cases is surmarized in the appendix. At the surface the usual assumption of zero radon concentration has been made. At the bottom of the tailings 


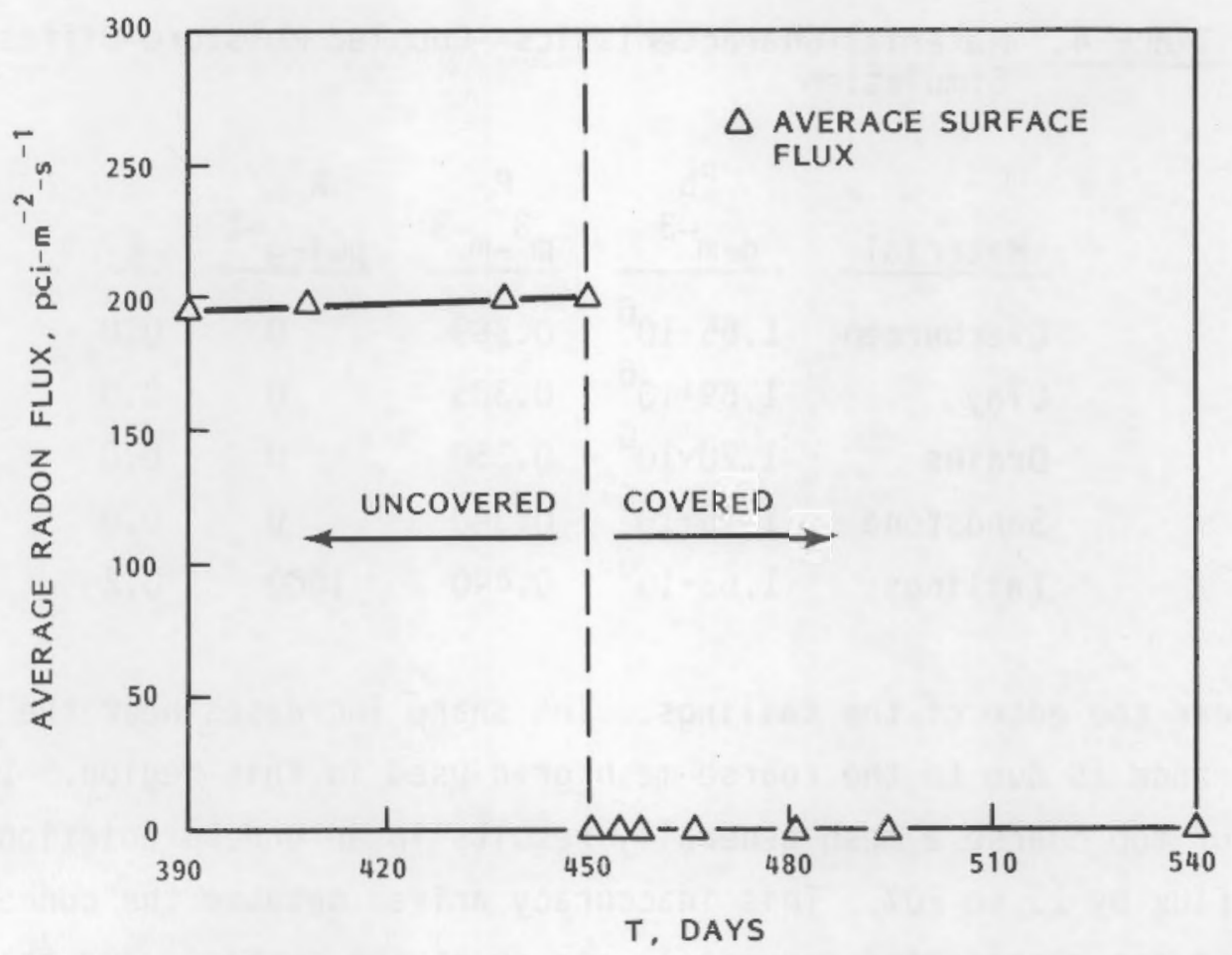

FIGURE 9. Average Surface Flux Before and After Pile Coverage

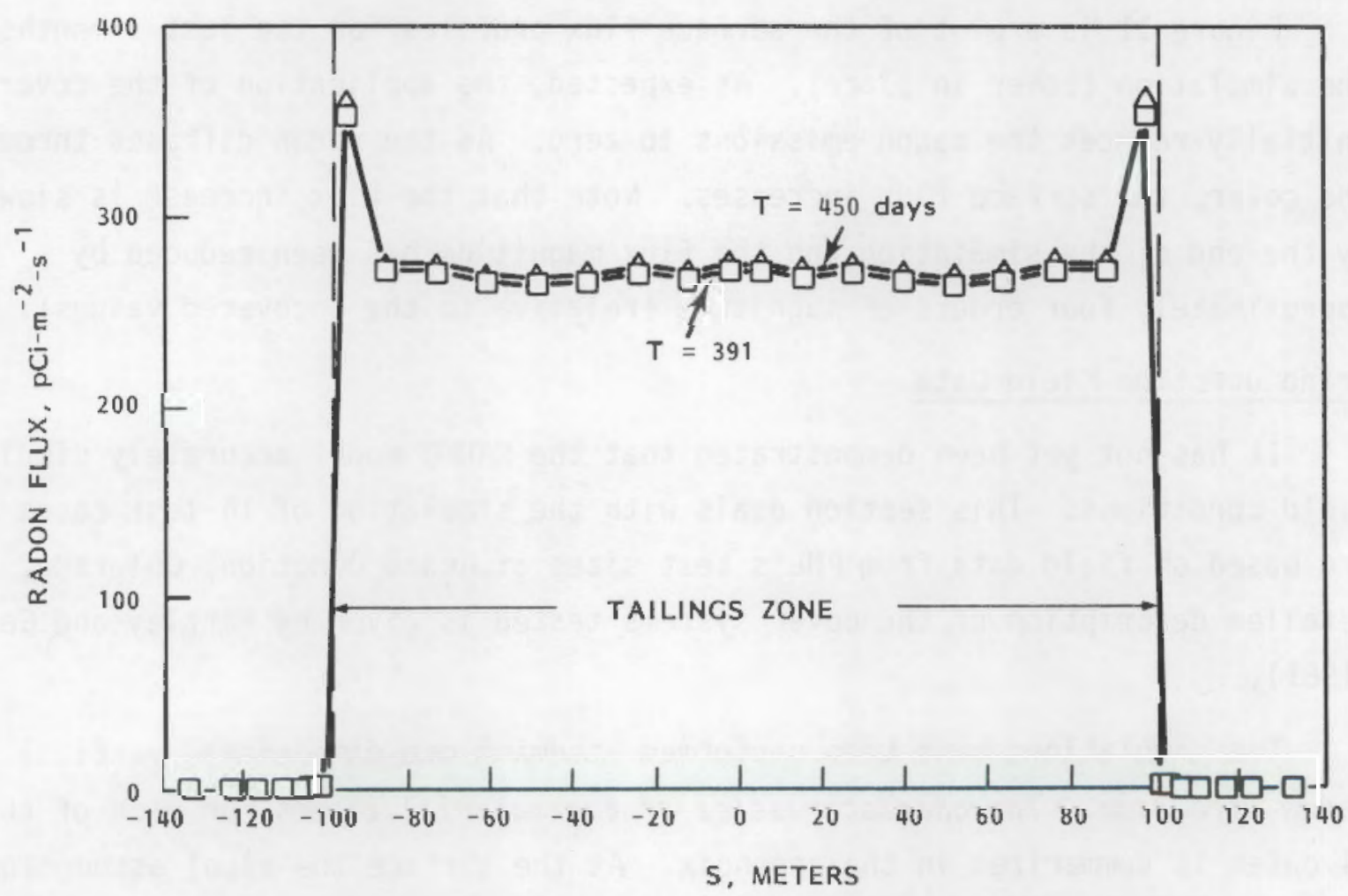

FIGURE 10. Surface Flux Profiles-Uncovered Tailings Pile 


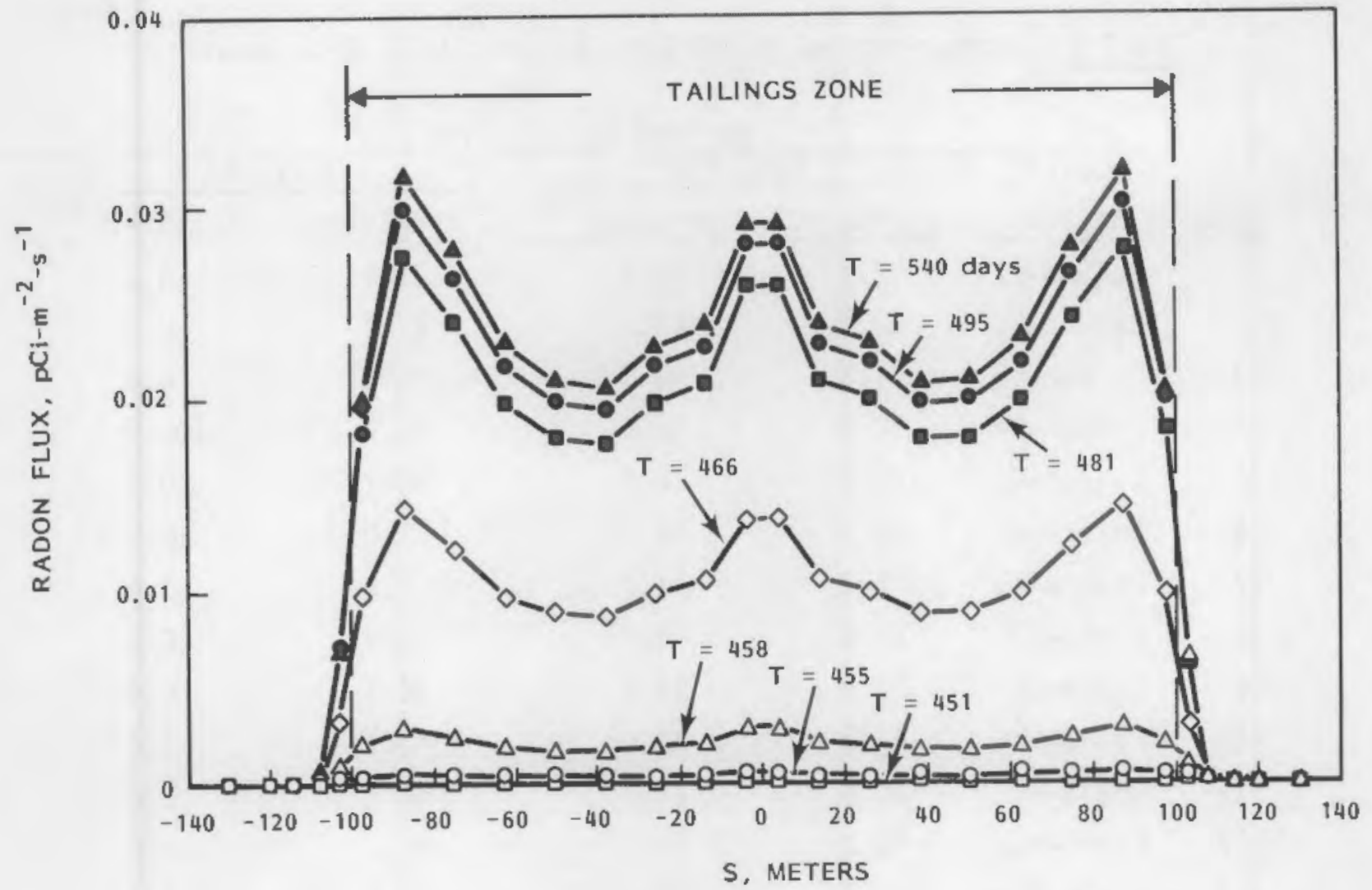

FIGURE 11. Surface Flux Profiles--Covered Tailings Pile

layer, zero flux has been specified. The results of the computer analysis along with the field observed values for the surface flux are summarized in Table 5 .

The data show that large variations in radon surface flux measurements occur both temporally and spatially. These variations are not accounted for by the present model. Several reasons may be offered for the poor agreement:

- High variability in the source term. The model assumes an unchanging, constant source term. Spatial variability of the source term may give rise to the large standard deviation observed on many test plots; however, it does not explain the large flux variation that occurred with time at the majority of the sampling points.

- Barometric pressure fluctuations influence radon exhalation. Some test data collected at the Grand Junction field site in July 1982 indicated that radon flux could vary by a factor of 2 between 12-hr 
TABLE 5. Comparison of Model Results and Field Observations

\begin{tabular}{|c|c|c|c|c|c|}
\hline \multirow[b]{3}{*}{ Case } & \multicolumn{5}{|c|}{ Surface Flux, $p C i-m^{-2}-s^{-1}$} \\
\hline & \multirow{2}{*}{$\begin{array}{r}\text { Cover } \\
\text { System }\end{array}$} & \multicolumn{2}{|c|}{ Feb. ' 82} & \multicolumn{2}{|c|}{ JuTy ' 82} \\
\hline & & Predicted & Measured (a) & Predicted & Measured $^{(a)}$ \\
\hline 1 & Column-E1 & 18.0 & 18.2 & 21.4 & 14.5 \\
\hline 2 & Column-E2 & 22.1 & 23.2 & 27.2 & 2.8 \\
\hline 3 & Column-E3 & 44.6 & 43.3 & 49.8 & 6.8 \\
\hline 4 & Column-E4 & 91.9 & 17.6 & 96.7 & 100.0 \\
\hline 5 & Column-Ml & 105.4 & 8.6 & 94.1 & 10.4 \\
\hline 6 & Column-M2 & 71.3 & 9.3 & 61.0 & 12.7 \\
\hline 7 & Column $-\mathrm{A} 1$ & 2.7 & 1.4 & 2.6 & 1.4 \\
\hline 8 & Field-E1 & 18.0 & 1.4 & 15.4 & 0.5 \\
\hline 9 & Field-E2 & 32.4 & 11.1 & 34.1 & 6.6 \\
\hline 10 & Field-E3 & 47.5 & 10.0 & 41.3 & 3.6 \\
\hline 11 & Field-E4 & 64.1 & 24.7 & 56.6 & 8.0 \\
\hline 12 & Field-ML1 & 50.3 & 12.0 & 44.7 & 6.0 \\
\hline 13 & Field-ML2 & 36.4 & 32.2 & 23.4 & 7.0 \\
\hline 14 & Field-ML3 & 45.3 & 19.2 & 34.8 & 8.3 \\
\hline
\end{tabular}

(a) The first seven cases (column tests) report averages of at least two measurements. The last seven cases (field cover tests) report averages of at least 10 measurements. The coefficient of variation (standard deviation/ mean value) approached 1 for most test cases.

dayt ime flux readings and $12-\mathrm{hr}$ nighttime readings. Fluxes were consistently higher during the night. There was a negative correlation between radon flux and barometric pressure change suggesting that a slight decrease (2 to $3 \mathrm{mbar}$ ) in pressure could cause the flux to increase. While barometric pressure changes may account for observed day-nite variations they would not account for the February to July measured decreases in radon flux.

- Inadequate relationship for predicting diffusion coefficients as a function of moisture content and porosity. The data indicate that tightly compacted multilayer and subsoil materials tend to have lower diffusion coefficients than predicted. There was no apparent 
relationship between profile moisture content changes and radon fiux changes observed between the February and July 1982 measurements (Compare Table 5 with moisture content data in Table A.2).

- Moisture and density measurements at selected points may be inadequate to describe the water content and density relationships of the entire cover system.

- Instrument error in radon flux measurements. No absolute standards are presently available for radon flux measurements. Relative flux measurements in the laboratory are reproducible within $\pm 12 \%$ for the tent system used on the Grand Junction test site (Hartley et al. 1981). Field measurements are subjected to temperature and wind conditions that may affect instrument readings or have a direct affect on the radon flux itself. Temperature extremes on the instrument as well as thermal gradients and wind gusts at the cover surface can give rise to variations in measurement of radon flux causing an "apparent" instrument error. The magnitude of these effects need to be evaluated. Duwe (1976) suggests that typical temperature and wind fluctuations will not significantly influence the radon flux if effects on instrumentation are ignored.

It is not known at this time the extent to which these factors are influencing the surface measurements. The radon flux can vary by more than an order of magnitude at a given site both diurnally and seasonally with no apparent change in cover moisture content. Additional field characterization will be needed in order to account for the high variability observed in flux measurements. Model simulations with fiela data awaits more definitive measurements of the surface radon flux and more detailed characterization of the cover material and radon source. 


\section{REFERENCES}

Duwe, M. P. 1976. The Diurnal Variation in Radon Flux from the Soil Due to Atmospheric Pressure Change and Turbulence. Ph.D. Thesis. University of Michigan, Ann Arbor, MI.

Gee, G. W. et al. 1981. "Radon Control by Multilayer Earth Barriers, 2: Field Tests." In Uranium Mill Tailings Management, Proceedings of the Fourth Symposium, 0ct. 26-27, 1981. pp. 289-308. Geotechnical Engineering Program, Civil Engineering Department, Colorado State University.

Hartley, J. N., and G. W. Gee. 1981. "Uranium Mill Tailings Remedial Action (UMTRA) Joint Field Test." In Uranium Mill Tailings Management, Proceedings of the Fourth Symposium, 0ct. 26-27, 1981. pp. 115-134. Geotechnical Engineering Program, Civil Engineering Department, Colorado State University.

Hartley, J. N. et al. 1981. "Field Testing of Asphait Emulsion Radon Barrier System." In Uranium Mill Tailings Management, Proceedings of the Fourth Symposium, 0ct. 26-27, 1981. pp. 319-342. Geotechnical Engineering Program, Civil Engineering Department, Colorado State University.

Mayer, D.W., C.A. Oster, R. W. Nelson and G. W. Gee. 1981. Radon Diffusion Through Multilayer Earthen Covers: Models and Simulations. PNL-3989, pacific Northwest Laboratory, Richland, Washington.

Narasimhan, T. N., and P. A. Witherspoon. 1977. "Numerical Model for Saturated-Unsaturated Flow of Deformable Porous Media 1. Theory." In Water Resources Research 13(3):657-664.

Nielson, K. K, et al. 1981. Laboratory Measurements of Radon Oiffusion through Multilayered Cover Systems for Uranium Tailings - UMT/0206. Pacific Northwest Laboratory, Richland, Wa.

Nelson, R. W., G. W. Gee and C. A. Oster. 1980. "Radon Control by Multilayer Earth Barriers, 1. Modeling of Moisture and Density Effects of Racon Diffusion from Uranium Mill Tailings." In Uranium Mill Tai]ings Management, Proceedings of the Third Symposium, November 24-25, 1980 . Pp. 79-88. Geotechnical Engineering Program, Civil Engineering Department, Colorado State University.

Reisenauer, A. E., K. T. Key, T. N. Narasimhan and R. W. Nelson, 1982. TRUST: A Computer Program for Variably Saturated Flow in Multidimensional, Deformable Media. PNL-3975, Pacific Northwest Laboratory, Richtand, Washington.

Rogers, V.C., et al. 1980. Characterization of Uranium Tailings Cover Materials for Radon Flux Reduction. NUREG/CR-108l, U.S. Nuclear Regulatory Comission, Washington, D.C. 
Sandquist, G. M., V. C. Rogers and K. K. Nielson. 1981. "The Analysis of Nonuniform Radon Flux Emanations." In Transactions of the American Nuclear Society, November 29 through December 3, 1981, ed. N. Z. GodTewski, Vol. 39, pp. 114-116. American Nuc Tear Society, Inc., La Grange Park, Ill inois.

Tanner, A. B. 1964. "Radon Migration in the Ground: A Review." In The Natural Radiation Environment, ed. J. A. S. Adans and W. M. Lowder, pp. 161-190. University of Chicago Press, Chicago, I1linois. 
APPENDIX

SUMMARY OF GRAND JUNCTION FIELD DATA 
APPENDIX

SUMMARY OF GRAND JUNCTION FIELD DATA

Figure A.1 is a schematic of a typical mill tailings pile with cover layers. This figure shows the conventions used in numbering layers and the thickness of layers. Table A.1 lists the thicknesses of the layers for each of the 14 Grand Junction test cases, and Table A.2 summarizes the material properties of the layers for each case.

The porosity for each layer was calculated by the following equation:

$$
P=1-\rho_{b} / \rho_{S}
$$

with the particle density, os assumed to be $2.7 \mathrm{~g}-\mathrm{cm}^{-3}$. The porosity and moisture content for each layer were then used to calculate the effective diffusivity, $D_{e}$, via Equation 5 . An exception to this procedure was the asphalt layer in Case 7 , where $D_{e}$ was assumed to be $1.0 \cdot 10^{-9} \mathrm{~m}^{2}-\mathrm{s}^{-1}$.

Grand Junction moisture content data were obtained by down hole logging with a neutron moisture meter. The bulk density measurements were obtained by coring and gravimetric sampling at selected points in the cover. For the earthen cover plots (cases 8 through 11 , 1 isted in Tables A.1 and A.2) two neutron probe access holes were monitored on each plot. For the multilayer cover plots (cases 12, 13 and 14) four neutron probe access holes were monitored on each plot. For the column tests (cases 1 through 7) a single access hole was monitored. Moisture and radon flux data are reported for dates in February and July 1982. The moisture data were obtained prior to final calibration of the neutron moisture probe so the absolute values may be in error by a few percent. However, the same calibration was used on the February and July data so the relative changes in water content should be realistic. Further analysis of the radon flux and moisture content changes with time at the Grand Junction test site will be presented in future reports. 


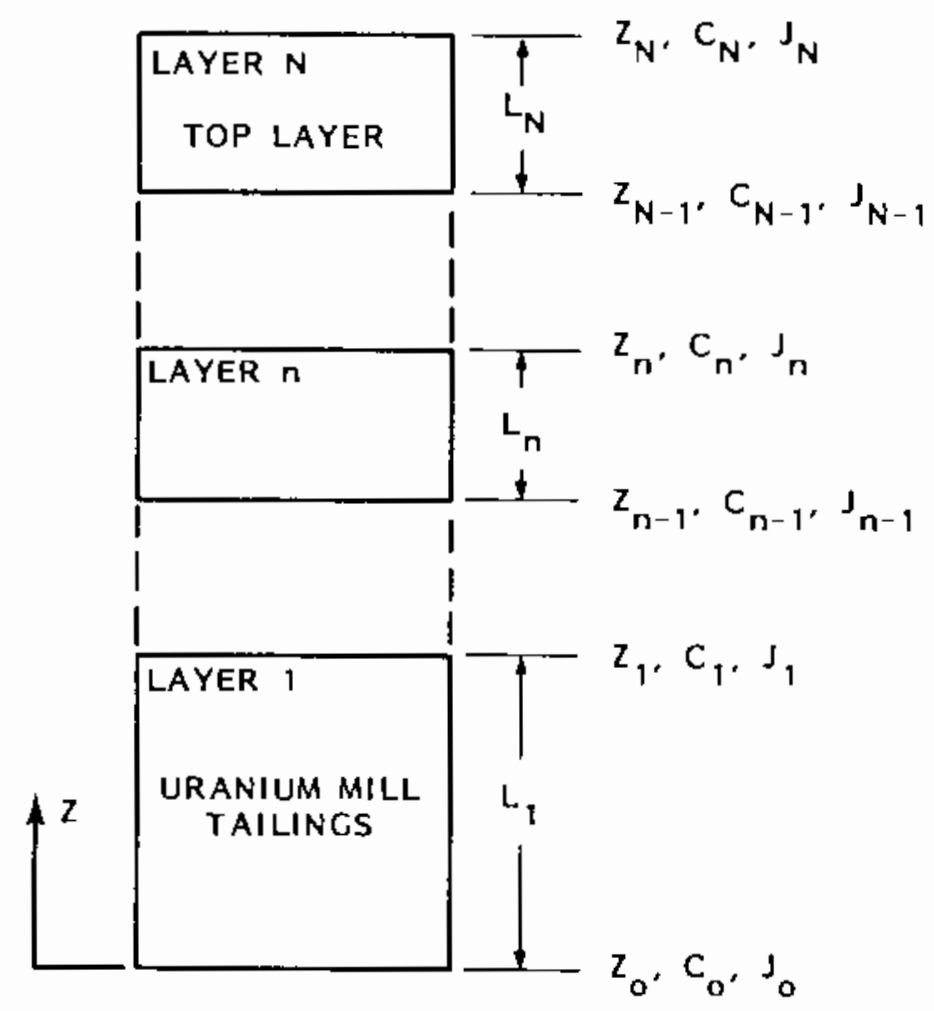

FIGURE A.1. Schematic of Mill Tailings and Cover Layers 
TABLE A.1. Layer Thickness

\begin{tabular}{rrrrrr} 
& \multicolumn{5}{c}{ Thickness, m } \\
\cline { 5 - 6 } 1 & $L_{1-}$ & $L_{2-}$ & $L_{3-}$ & $L_{4-}$ & $\underline{L}_{5-}$ \\
2 & 7.9 & 1.2 & 1.8 & & \\
3 & 7.9 & 1.2 & 1.8 & & \\
4 & 7.9 & 1.2 & 1.8 & & \\
5 & 7.9 & 3.0 & & & \\
6 & 9.9 & 0.4 & 0.2 & 1.4 & \\
7 & 10.2 & 0.3 & 0.2 & 1.2 & \\
8 & 7.6 & 1.2 & 2.1 & & \\
9 & 7.9 & 1.2 & 1.8 & & \\
10 & 7.9 & 1.2 & 1.8 & & \\
11 & 7.9 & 3.0 & & & \\
12 & 9.3 & 0.1 & 0.15 & 0.23 & 1.0 \\
13 & 9.2 & 0.1 & 0.3 & 0.23 & 1.0 \\
14 & 9.2 & 0.1 & 0.4 & 0.23 & 1.0
\end{tabular}


TABLE A.2. Material Data

\begin{tabular}{|c|c|c|c|c|c|c|c|}
\hline Case & Layer & Material & $\begin{array}{c}\mathrm{R} \\
\mathrm{pCi}-\mathrm{q}^{-1}\end{array}$ & $\mathrm{E}$ & ${ }_{\mathrm{g}}^{\mathrm{D}_{\mathrm{b}}-\mathrm{m}^{-3}}$ & $\begin{array}{l}\text { Feb. }{ }^{182} \\
m^{3}-m^{-3}\end{array}$ & $\begin{array}{l}\text { July' } 1 y^{\prime} 82 \\
3-m^{-3} \\
m^{3}-m^{2}\end{array}$ \\
\hline 1 & $\begin{array}{l}\mathrm{L}_{3} \\
\mathrm{~L}_{2} \\
\mathrm{~L}_{1}\end{array}$ & $\begin{array}{l}\text { Adobe } \\
\text { Mancos } \\
\text { Tailings }\end{array}$ & $\begin{array}{r}0 \\
0 \\
1900\end{array}$ & $\begin{array}{l}0 \\
0 \\
0.22\end{array}$ & $\begin{array}{l}1.69 \cdot 10^{6} \\
1.77 \cdot 10^{6} \\
1.12 \cdot 10^{6}\end{array}$ & $\begin{array}{l}0.07 \\
0.16 \\
0.18\end{array}$ & $\begin{array}{l}0.05 \\
0.15 \\
0.17\end{array}$ \\
\hline 2 & $\begin{array}{l}\mathrm{L}_{3} \\
\mathrm{~L}_{2} \\
\mathrm{~L}_{1}\end{array}$ & $\begin{array}{l}\text { Adobe } \\
\text { Bentonite } \\
\text { Tailings }\end{array}$ & $\begin{array}{r}0 \\
0 \\
1900\end{array}$ & $\begin{array}{l}0 \\
0 \\
0.22\end{array}$ & $\begin{array}{l}1.57 \cdot 10^{6} \\
1.35 \cdot 10^{6} \\
1.12 \cdot 10^{6}\end{array}$ & $\begin{array}{l}0.06 \\
0.32 \\
0.18\end{array}$ & $\begin{array}{l}0.05 \\
0.30 \\
0.17\end{array}$ \\
\hline 3 & $\begin{array}{l}\mathrm{L}_{3} \\
\mathrm{~L}_{2} \\
\mathrm{~L}_{1}\end{array}$ & $\begin{array}{l}\text { Adobe } \\
\text { Compact Adobe } \\
\text { Tailings }\end{array}$ & $\begin{array}{r}0 \\
0 \\
1900\end{array}$ & $\begin{array}{l}0 \\
0 \\
0.22\end{array}$ & $\begin{array}{l}1.45 \cdot 10^{6} \\
1.69 \cdot 10^{6} \\
1.12 \cdot 10^{6}\end{array}$ & $\begin{array}{l}0.06 \\
0.12 \\
0.17\end{array}$ & $\begin{array}{l}0.05 \\
0.11 \\
0.19\end{array}$ \\
\hline 4 & $\begin{array}{l}\mathrm{L}_{2} \\
\mathrm{~L} 1\end{array}$ & $\begin{array}{l}\text { Adobe } \\
\text { Tailings }\end{array}$ & $\begin{array}{r}0 \\
1900\end{array}$ & $\begin{array}{l}0 \\
0.22\end{array}$ & $\begin{array}{l}1.35 \cdot 10^{6} \\
1.12 \cdot 10^{6}\end{array}$ & $\begin{array}{l}0.05 \\
0.17\end{array}$ & $\begin{array}{l}0.04 \\
0.18\end{array}$ \\
\hline 5 & $\begin{array}{l}\mathrm{L}_{4} \\
\mathrm{~L}_{3} \\
\mathrm{~L}_{2} \\
\mathrm{~L}_{1}\end{array}$ & $\begin{array}{l}\text { Adobe } \\
\text { Rock } \\
\text { Bentonite/Gravel } \\
\text { Tailings }\end{array}$ & $\begin{array}{r}0 \\
0 \\
0 \\
1900\end{array}$ & $\begin{array}{l}0 \\
0 \\
0 \\
0.22\end{array}$ & $\begin{array}{l}1.56 \cdot 10^{6} \\
1.75 \cdot 10^{6} \\
1.67 \cdot 10^{6} \\
1.12 \cdot 10^{6}\end{array}$ & $\begin{array}{l}0.06 \\
0.01 \\
0.17 \\
0.16\end{array}$ & $\begin{array}{l}0.05 \\
(\mathrm{a}) \\
0.20 \\
0.16\end{array}$ \\
\hline 6 & $\begin{array}{l}\mathrm{L}_{4} \\
\mathrm{~L}_{3} \\
\mathrm{~L}_{2} \\
\mathrm{~L} \cdot \mathrm{l}\end{array}$ & $\begin{array}{l}\text { Adobe } \\
\text { Rock } \\
\text { Alum/Gravel } \\
\text { Tailings }\end{array}$ & $\begin{array}{r}0 \\
0 \\
0 \\
1900\end{array}$ & $\begin{array}{l}0 \\
0 \\
0 \\
0.22\end{array}$ & $\begin{array}{l}1.45 \cdot 10^{6} \\
1.75 \cdot 10^{6} \\
1.94 \cdot 10^{6} \\
1.12 \cdot 10^{6}\end{array}$ & $\begin{array}{l}0.06 \\
0.01 \\
0.18 \\
0.18\end{array}$ & $\begin{array}{l}0.05 \\
(a) \\
0.19 \\
0.18\end{array}$ \\
\hline 7 & $\begin{array}{l}L_{3} \\
L_{2} \\
L_{1}\end{array}$ & $\begin{array}{l}\text { Adobe } \\
\text { Asphalt } \\
\text { Tailings }\end{array}$ & $\begin{array}{r}0 \\
0 \\
1900\end{array}$ & $\begin{array}{l}0 \\
0 \\
0.22\end{array}$ & $\begin{array}{l}1.60 \cdot 10^{6} \\
\text { (b) } \\
1.12 \cdot 10^{6}\end{array}$ & $\begin{array}{l}0.07 \\
\text { (b) } \\
0.18\end{array}$ & $\begin{array}{l}0.06 \\
\text { (b) } \\
0.18\end{array}$ \\
\hline 8 & $\begin{array}{l}L_{3} \\
L_{2} \\
L_{1}\end{array}$ & $\begin{array}{l}\text { Adobe } \\
\text { Mancos } \\
\text { Tailngs }\end{array}$ & $\begin{array}{r}0 \\
0 \\
1818\end{array}$ & $\begin{array}{l}0 \\
0 \\
0.2\end{array}$ & $\begin{array}{l}1.42 \cdot 10^{6} \\
1.75 \cdot 10^{6} \\
1.20 \cdot 10^{6}\end{array}$ & $\begin{array}{l}0.12 \\
0.16 \\
0.19\end{array}$ & $\begin{array}{l}0.11 \\
0.18 \\
\text { (a) }\end{array}$ \\
\hline 9 & $\begin{array}{l}\mathrm{L}_{3} \\
\mathrm{~L}_{2} \\
\mathrm{~L}_{1}\end{array}$ & $\begin{array}{l}\text { Adobe } \\
\text { Bentonite } \\
\text { Tailings }\end{array}$ & $\begin{array}{r}0 \\
0 \\
1818\end{array}$ & $\begin{array}{l}0 \\
0 \\
0.2\end{array}$ & $\begin{array}{l}1.42 \cdot 10^{6} \\
1.38 \cdot 10^{6} \\
1.20 \cdot 10^{6}\end{array}$ & $\begin{array}{l}0.15 \\
0.23 \\
0.20\end{array}$ & $\begin{array}{l}0.14 \\
0.23 \\
\text { (a) }\end{array}$ \\
\hline 10 & $\begin{array}{l}L_{3} \\
L_{2} \\
L_{1}\end{array}$ & $\begin{array}{l}\text { Adobe } \\
\text { Compacted Adobe } \\
\text { Tailings }\end{array}$ & $\begin{array}{r}0 \\
0 \\
1818\end{array}$ & $\begin{array}{l}0 \\
0 \\
0.2\end{array}$ & $\begin{array}{l}1.42 \cdot 10^{6} \\
1.50 \cdot 10^{6} \\
1.20 \cdot 10^{6}\end{array}$ & $\begin{array}{l}0.10 \\
0.14 \\
0.17\end{array}$ & $\begin{array}{l}0.11 \\
0.15 \\
\text { (a) }\end{array}$ \\
\hline 11 & $\begin{array}{l}\mathrm{L}_{2} \\
\mathrm{~L}_{1}\end{array}$ & $\begin{array}{l}\text { Adobe } \\
\text { Tailings }\end{array}$ & $\begin{array}{r}0 \\
1818\end{array}$ & $\begin{array}{l}0 \\
0.2\end{array}$ & $\begin{array}{l}1.42 \cdot 10^{6} \\
1.20 \cdot 10^{6}\end{array}$ & $\begin{array}{l}0.08 \\
0.17\end{array}$ & $\begin{array}{l}0.10 \\
\text { (a) }\end{array}$ \\
\hline
\end{tabular}


IABLE A.2. (cont d)

\begin{tabular}{|c|c|c|c|c|c|c|c|}
\hline Case & Layer & Material & $\begin{array}{c}R \\
p C i-g^{-1}\end{array}$ & $\mathrm{E}$ & ${ }_{g-m}^{\rho_{b}}-3$ & $\begin{array}{l}\text { Feb. } 82 \\
m^{3}-m^{-3}\end{array}$ & $\begin{array}{l}\text { July'82 } \\
m^{3}-m^{-3}\end{array}$ \\
\hline 12 & $\begin{array}{l}L_{5} \\
L_{4} \\
L_{3} \\
L_{2} \\
L_{1}\end{array}$ & $\begin{array}{l}\text { Adobe } \\
\text { Rock } \\
\text { Alum Mix } \\
\text { Soil } \\
\text { Tailings }\end{array}$ & $\begin{array}{r}0 \\
0 \\
0 \\
350 \\
714\end{array}$ & $\begin{array}{l}0 \\
0 \\
0 \\
0.2 \\
0.2\end{array}$ & $\begin{array}{l}1.42 \cdot 10^{6} \\
1.60 \cdot 10^{6} \\
1.94 \cdot 10^{6} \\
1.40 \cdot 10^{6} \\
1.20 \cdot 10^{6}\end{array}$ & $\begin{array}{l}0.06 \\
0.01 \\
0.17 \\
0.06 \\
0.07\end{array}$ & $\begin{array}{l}0.05 \\
(\mathrm{a}) \\
0.18 \\
(\mathrm{a}) \\
0.06\end{array}$ \\
\hline 13 & $\begin{array}{l}L_{5} \\
L_{4} \\
L_{3} \\
L_{2} \\
L_{1}\end{array}$ & $\begin{array}{l}\text { Adobe } \\
\text { Rock } \\
\text { Alum Mix } \\
\text { Soil } \\
\text { Tailings }\end{array}$ & $\begin{array}{r}0 \\
0 \\
0 \\
350 \\
714\end{array}$ & $\begin{array}{l}0 \\
0 \\
0 \\
0.2 \\
0.2\end{array}$ & $\begin{array}{l}1.42 \cdot 10^{6} \\
1.60 \cdot 10^{6} \\
1.96 \cdot 10^{6} \\
1.40 \cdot 10^{6} \\
1.20 \cdot 10^{6}\end{array}$ & $\begin{array}{l}0.05 \\
0.01 \\
0.15 \\
0.06 \\
0.07\end{array}$ & $\begin{array}{l}0.04 \\
(\mathrm{a}) \\
0.18 \\
(\mathrm{a}) \\
0.07\end{array}$ \\
\hline 14 & $\begin{array}{l}L_{5} \\
L_{4} \\
L_{3} \\
L_{2} \\
L_{1}\end{array}$ & $\begin{array}{l}\text { Adobe } \\
\text { Rock } \\
\text { Clay/Lime Mix } \\
\text { Soil } \\
\text { Tailings }\end{array}$ & $\begin{array}{r}0 \\
0 \\
0 \\
350 \\
714\end{array}$ & $\begin{array}{l}0 \\
0 \\
0 \\
0.2 \\
0.2\end{array}$ & $\begin{array}{l}1.42 \cdot 10^{6} \\
1.60 \cdot 10^{6} \\
1.92 \cdot 10^{6} \\
1.40 \cdot 10^{6} \\
1.20 \cdot 10^{6}\end{array}$ & $\begin{array}{l}0.05 \\
0.01 \\
0.12 \\
0.07 \\
0.08\end{array}$ & $\begin{array}{l}0.05 \\
(\mathrm{a}) \\
0.15 \\
(\mathrm{a}) \\
0.09\end{array}$ \\
\hline
\end{tabular}

(a) Value not measured. Used February dąta.

(b) $\mathrm{D}_{\mathrm{e}}$ assumed to be equal to $1 \times 10^{-9} \mathrm{~m}^{2}-\mathrm{s}^{-1}$ 


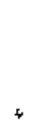




\section{OISTRIBUTION}

No. of

Copies

OFFSITE

27 DOE Technical Information Center

W. E. Mott, Director

Environmental and Safety

Engineering Division

U.S. Department of Energy, EP-14

Washington, DC 20545

R. W. Ramsey, Jr., Program Mgr

Remedial Actions Program, NE-301

U.S. Department of Energy

Washington, DC 20545

E. Delaney, Remedial Actions Program

Office of Nuclear Waste

Management

U.S. Department of Energy, NE-301

Washington, DC 20545

20 0. H. Groelsema

Remedial Actions Program

Dffice of Nuclear Waste

Management

U.S. Department of Energy, NE-301

Washington, DC 20545

A. Kluk, Remedial Actions

Program

Office of Nuclear Waste

Management

U.S. Department of Energy, $\mathrm{NE}-301$

Washington, DC 20545

R. Dale Smith, Chief

Uranium Recovery License Branch

Mail Station 483-SS

U.S. Nuclear Regularory

Commission

Washington, DC 20555
No. of

Copies

William Nixon

Office of Nuclear Materials, Safety and Safeguards

Mail Station 396-SS

U.S. Nuclear Regulatory Commission

Washington, DC 20555

George Birchard

Mail Station 1130-SS

U.S. Nuclear Regulatory

Commi ssion

Washington, DC 20555

Stanley Lichtman, Criteria and

Standards Division

Office of Radiation Programs

U.S. Environmental Protection Agency

Washington, DC 20460

J. White, Chief

Reactor Operations Branch

U.S. Department of Energy

Richland, Operations Office

825 Jadwin Avenue

P.0. Box 550

Richland, WA 99352

E. L. Keller, Director

Technical Services Division

U.S. Department of Energy

0 ak Ridge Operations Office

P.O Box E

Oak Ridge, TN 37830

T. M. Gerusky, Director

Bureau of Radiation Protection

P.0. Box 2063

Harrisburg, PA 17120 
No. of

Copies

A. J. Hazle, Director

Radiation and Hazardous Wastes Division

Colorado Department of Health

4210 East 1lth Avenue

Denver, C0 80220

E. D. Bailey, Administrator

Radiation Control Branch

Texas Department of Health

1100 W. 49th Street

Austin, TX 78756

Larry Anderson, Director

Bureau of Radiation and

Occupational Health

P.0. Box 2500

Salt Lake City, UT 84110

Walt Ackerman, Director

Department of Environmental Quality

Land Quality Division

Hathaway Building

Cheyenne, WY 82002

Lynn Fitzrandolph

Arizona Atomic Energy Commission

2929 West Indian School Road

Phoenix, AZ 85017

Ted Wolfe, Enviromental Manager

Radiation Department

P.0. Box 968

Santa Fe, NM 87503

Lynn Frank, Director

Oregon Department of Energy

111 Labor and Industries Building

Salem, Oregon 97310

D. K. Mount, Director

Division of Environmental

Engineering

North Dakota State Department of Health

1200 Missourj Avenue, Room 304

Bismarck, ND 58505
No. of

Copies

Robert Funderberg

Department of Health and Welfare

Statehouse

Boise, Idaho 83707

Harold Tso, Executive Director

Environment al Protection Commission

The Navajo Nation

Window Rock, AZ 86515

2 J. W. Mckiernan

Organization 4542

Sandia National LaboratoryAlbuquerque

P.0. Box 5800

Albuquerque, NM 87185

Mark A. Jackson

Jacobs Engineering

5301 Central Avenue NE

Suite 1700

Albuquerque, NM 87108

Walt Barber

Jacobs Engineering

5301 Central Avenue NE

Suite 1700

Albuquerque, NM 87108

Gergely Markos, Ph.D.

Research Institute for

Geochemistry and Environmental

Chemistry

2693 Commerce Road

Rapid City, SD 57701

Walt Kisieleski

Argonne National Laboratory

9700 South Cass Avenue

Argonne, IL 60439

J. D. Nelson, Ph.D., P.E. Professor, Program Leader Colorado State University

Fort Collins, CO 80523 
No. of

Copies

D. E. Large, Program Manger Radioactive Waste Mangement Program

P.0. Box E

Oak Ridge, TN 37830

\author{
A. A. Metry \\ Weston \\ Weston Way \\ West Chester, PA 19380 \\ R. Neff \\ Mound Facility \\ c/o Dayton Area Office \\ P.0. Box 66 \\ Mi ami sburg, OH 45342 \\ K. R. Porter \\ Danies \& Moore \\ 1626 Cole Blvd \\ Golden, CO 80401
}

A. Ryon

Oak Ridge National Laboratory

P.0. Box $X$

Oak Ridge, TN 37830

T. N. Narasimhan

Lawrence Berkeley Laboratory

Berkeley, CA 94720

T. Tamura

Oak Ridge National Laboratory

P.0. Box X

Oak Ridge, TN 37830

George Stukenbroeker

NLO, Inc.

P.0. Box 39158

Cincinnati, $\mathrm{OH} \quad 45239$

Aivin Askew

Politech Corporation

2220 Aust in National Bank Tower Austin, TX 78701
No. of

Copies

M. L. Matthews, Project Engineer Uranium Mill Tailings Project Office

P.0. Box 5400

Albuque rque, NM 87115

50 R. H. Campbell, Project Manager

Uranium Mill Tailings Project Off ice

U.S. Department of Energy

P.0. Box 5400

Albuque rque, NM 87115

V. C. Rogers, President

Rogers \& Associates Engineering

445 East 200 South, Suite 303

Salt Lake City, UT 84111

Robert Overmyer

Ford, Bacon \& 0avis Utah

375 Chipeta Way

P.0. Box 8009

Salt Lake City, UT 84108

Dave Oreesen

Los Alamos National Laboratory

P.0. Box 1663

Los Alamos, NM 87545

Off ice of the Assistant Manager for Energy Research and

Development

DOE Oak Ridge Operations office

P.0. Box E

Oak Ridge, TN 37830

W. Chappel

Center for Environmental Sciences

University of Colorado

1015 Ninth Street

Denver, CO 80202

ONSITE

OOE Richland Operations Office

H. E. Ransom 
No. of

Copies

64 Pacific Northwest Laboratory
S. M. Brown
J. L. Buelt
L. L. Cadwel]
D. B. Cearlock
G. W. Gee (20)
J. N. Hartley
T. L. Jones
H. D. Freeman
J. V. Robinson

No. of

Copies
D. R. Kalkwarf
D. W. Mayer (20)
R. W. Nelson
C. A. Oster
M. G. Foley
Technical Information (5)
Publishing Coordination BE(2)
Geosciences Research and Engineering Department Library (5) 